\title{
DINAMIKA PRODUKTIVITAS PADI DITINJAU DARI FLUKTUASI SUSUT HASIL SERTA FAKTOR SOSIAL, EKONOMI DAN BUDAYA YANG MEMPENGARUHINYA
}

\author{
Elly Rasmikayati $^{1^{*}}$ dan Asep Faisal $^{2}$ \\ ${ }^{1}$ Departemen Sosektan Fakultas Pertanian Universitas Padjadjaran, Jatinangor \\ ${ }^{2}$ Dinas Pertanian Tanaman Pangan dan Holtikultura, Kota Bandung \\ Email: elly.agri@yahoo.co.id
}

\begin{abstract}
ABSTRAK
Upaya-upaya pemerintah dalam meningkatkan produksi pangan dalam rangka mencapai swasembada pangan masih terus dilakukan. Namun di sisi lain, kehilangan akibat tingkat susut hasil padi yang tinggi menjadi salah satu permasalahan nyata yang harus segera diatasi. Tujuan dari artikel ini adalah mengidentifikasi dinamika produktivitas padi Jawa Barat, memaparkan dinamika variasi susut hasil padi di Jawa Barat dan mengidentifikasi faktor-faktor non teknis apa saja yang mempengaruhi susut hasil padi. Metode yang digunakan adalah two-phase mixed method. Hasil penelitian mengungkapkan terjadinya fluktuasi yang lebih tajam dan laju pertumbuhan yang lebih lambat pada produtivitas padi Jawa Barat dibandingkan Jawa Tengah dan Jawa Timur, kemudian dinamika variasi susut hasil di Jawa Barat masih cukup memprihatinkan dan belum ada kecenderungan untuk turun, selama kurun waktu 3 tahun selalu berada di level tertinggi pada 11,46 $\%$. Hasil analisis jalur menunjukkan bahwa terdapat faktor-faktor non teknis yang menjadi determinan terhadap susut hasil padi yaitu faktor pendapatan usahatani, luas lahan, perasaan, norma dan penggilingan. Implikasi kebijakan untuk mengatasi tingkat susut hasil gabah dan beras antara lain mendorong petani untuk lebih memperhatian pembiayaan untuk perlakuan panen dan pasca panen padi untuk menurunkan susut hasil.
\end{abstract}

Kata kunci: produktivitas padi, susut hasil padi, faktor sosial, faktor ekonomi, faktor budaya

\begin{abstract}
Government efforts to increase food production in order to achieve food self-sufficiency is still underway. But on the other hand, the loss due to high yield losses of rice to be one of the real problems that must be addressed immediately. The purpose of this article is to reveal the dynamics rice production in West Java, reveal the dynamics of variation of losses rice result in West Java, and identifies non-technical factors that influence rice yield losses. The method used is a two-phase mixed method. Results of the study revealed that occur the sharper fluctuation and slower growth rate in rice productifity in West Java compared to Central Java and East Java, then the dynamics of the variation of losses results in West Java is still quite alarming and there is no tendency to go down, during a period of 3 years has always been at the highest level at $11.46 \%$. The path analysis result showed that there are non-technical factors that determine rice yield losses including farm income, land area, feelings, norms and milling factors. The implication policies to overcome rice yield losses are encouraging farmers to pay more attention for the cost of harvest/post-harvest treatment to reduce rice yield losses.
\end{abstract}

Keywords: rice productivity, rice yield losses, social factor, economics factor, culture factor

\section{PENDAHULUAN}

Pertambahan penduduk selalu berdampak pada peningkatan kebutuhan akan pangan, hal ini mendorong berbagai upaya untuk meningkatkan produksi pangan. Dalam upaya meningkatkan swasembada pangan khususnya beras, saat ini pemerintah sedang melakukan berbagai upaya peningkatan produksi beras melalui perluasan areal dan optimalisasi lahan, peningkatan produktivitas padi melalui bantuan benih, pupuk, alat mesin pertanian dan revitalisasi penggilingan padi dan upaya-upaya lainnya.

Dalam 10 tahun terakhir (2004-2014), Jawa Barat merupakan penyumbang produksi padi terbesar kedua setelah Jawa Timur dengan 
rata-rata produksinya sebesar 10.775 .158 ton per tahun. Berdasarkan Gambar 1, yang paling mencolok adalah produksi padi Jawa Barat tahun 2009-2011 yang lebih besar dari Jawa Timur, bahkan pada tahun 2011 pada saat Jawa Timur dan Jawa Tengah mengalami penurunan produksi yang sangat mencolok, Jawa Barat hanya mengalami penurunan yang sangat sedikit. Namun demikian dari 2012 sampai sekarang, produksi padi Jawa Timur selalu di atas Jawa Barat dengan selisih yang terlihat cukup mencolok.

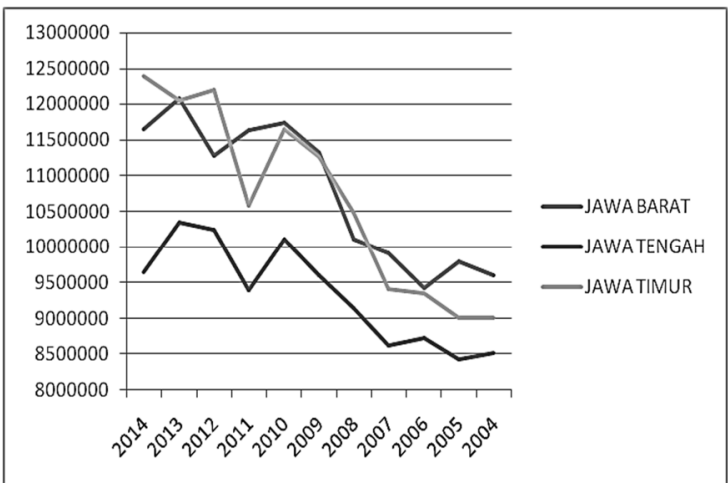

Gambar 1. Grafik Produksi Padi Jawa Barat, Jawa Tengah dan Jawa Timur periode 20042014 Sumber: Data BPS, diolah 2015

Turunnya produktivitas Jawa Barat dibandingkan Jawa Timur ini bisa disebabkan oleh banyak faktor diantaranya karena tidak maksimalnya penggunaan input pertanian seperti benih, pupuk, pestisida dan teknologi produksi lainnya. Selain itu fenomena perubahan iklim juga turut mempengaruhinya. Menurut Rasmikayati (2014) terdapat kecenderungan bahwa tindakan adiptif dan mitigatif terhadap perubahan iklim petani Jawa Timur lebih baik dari pada Jawa Barat. Penyebab lain yang sangat rasional adalah terjadinya susut hasil padi yang cukup tinggi di Jawa Barat.

Susut hasil dapat terjadi sejak panen hingga pascapanen. Panen dan pascapanen padi adalah tahapan kegiatan yang meliputi pemungutan (pemanenan) malai padi, perontokan, pembersihan, pengangkutan, pengeringan, penggilingan, penyimpanan sampai beras siap dipasarkan atau dikonsumsi. Apabila susut hasil dapat ditekan serendah mungkin, maka upaya peningkatan produksi padi dan beras dapat dicapai lebih efektif serta tidak akan mengeluarkan biaya yang terlalu besar.
Hasil penelitian Setyono (2008) menunjukkan bahwa Jawa Barat dibandingkan dengan Jawa Tengah, Lampung, Bali dan Kalimantan Selatan masih tertinggi persentase susut hasil padinya. Dengan persentase susut hasil Jawa Barat yang diatas 10\% ini merupakan angka yang sangat tinggi dan jelas akan berdampak pada jumlah produksi padi yang dihasilkan Jawa Barat.

Tabel 1. Perbandingan Susut Hasil, Jabar, Jateng, Lampung, Bali dan Kalsel

\begin{tabular}{|c|c|c|c|c|c|}
\hline \multirow[t]{2}{*}{ Tahapan } & \multicolumn{5}{|c|}{ Persentase Susut Hasil (\%) } \\
\hline & Jabar & Jateng & $\begin{array}{l}\text { Lam- } \\
\text { pung }\end{array}$ & Bali & Kalsel \\
\hline Panen & 3,56 & 1,88 & 2,80 & 1,34 & 1,53 \\
\hline Perontokan & 3,64 & 2,85 & 4,45 & 4,20 & 0,32 \\
\hline Pembersihan & - & 0,65 & 1,52 & - & - \\
\hline Pengangkutan & 1,13 & 0,49 & 1,40 & 0,67 & 1,46 \\
\hline Pengeringan & 1,82 & 2,18 & 1,49 & 1,90 & 1,15 \\
\hline Penggilingan & 2,14 & 2,57 & 1,51 & 1,22 & 1,58 \\
\hline Penyimpanan & 1,65 & - & - & 1,75 & 1,35 \\
\hline Jumlah & 13,94 & 10,62 & 13,24 & 11,08 & 7,39 \\
\hline
\end{tabular}

Sumber: Setyono, (2008)

Pemerintah pusat maupun daerah sebenarnya terus berupaya untuk menekan persentase susut hasil ini melalui bantuan fasilitasi alat dan mesin pertanian (alsintan) serta bimbingan tehnis penanganan panen dan pascapanen dengan target agar susut hasil gabah dan beras dapat ditekan untuk mencapai target $1 \%$ per tahun. Namun faktanya susut hasil berfluktuasi dan kalaupun turun jarang mencapai angka $1 \%$. Dengan demikian, upayaupaya pemerintah dalam menekan susut hasil padi ini belum begitu berjalan dengan baik ditingkat petani, Kelompok Tani maupun Gapoktan. Hal itu menunjukan bahwa selain faktor teknis terdapat juga faktor-faktor non teknis yang mempengaruhi tingginya persentase susut hasil padi dan beras.

Faktor sosial, ekonomi dan budaya masyarakat petani merupakan faktor-faktor non teknis yang mungkin dapat mempengaruhi perilaku petani, buruh tani, maupun penggarap. Sistem sosial ekonomi dan budaya ini sukar untuk berubah, meskipun berbagai introduksi teknologi maupun inovasi baru terus dilakukan, dahulu adanya penolakan mekanisasi di beberapa daerah misalnya. Kemudian sistem panen keroyokan, pengasag, remi, odong-odong, dan ngeprek merupakan salah satu budaya dari masyarakat petani yang masih terjadi sampai saat ini. Pemilik lahan, petani, petani penyakap atau petani penggarap 
tidak bisa mencegah perilaku tersebut karena itu telah ada dan merupakan budaya dari masyarakat petani. Pertanyataannya adalah faktor-faktor non teknis apa saja yang mempengaruhi tingginya persentase susut hasil padi dan beras.

Selanjutnya, dari Tabel 1 didapatkan bahwa rata-rata persentase susut hasil padi berdasarkan hasil penelitian Setyono (2008) adalah sebesar 13,94\%. Hal ini menunjukkan bahwa ternyata kita telah kehilangan hasil produksi padi dengan angka yang cukup besar. Kehilangan produksi padi ini harus dicegah atau diturunkan sampai seminimal mungkin agar dapat mencapai peningkatan produksi. Oleh karena itu tujuan dari artikel ini adalah 1) Memaparkan dinamika dan komparasi produktivitas padi Jawa Barat dari dahulu hingga saat ini; 2) Memaparkan dinamika variasi susut hasil padi di Jawa Barat; dan 3) Mengidentifikasi faktor-faktor non teknis apa saja yang mempengaruhi susut hasil padi sehingga dari sini kita dapat menentukan implikasi kebijakan untuk mengatasi susut hasil.

\section{KERANGKA TEORI}

Jawa Barat memang masih merupakan provinsi yang termasuk ke dalam 3 besar provinsi penyumbang produksi padi nasional. Namun demikian produksi padinya selalu mengalami fluktuasi naik turun. Terdapat beberapa faktor yang dapat menjadi penyebabnya diantaranya tidak maksimalnya input pertanian yang digunakan, terjadinya fenomena perubahan iklim dan yang terakhir adalah angka susut hasil padi Jawa Barat yang cukup besar. Untuk mengatasi susut hasil ini berbagai upaya telah dilakukan oleh pemerintah, namun hasilnya masih jauh dari target.

Faktor-faktor non teknis seperti faktor sosial, ekonomi, budaya seperti: umur, pendidikan, pendapatan, luas lahan, pengalaman berusahatani, pengawasan, perasaan, kepercayaan, sangsi sosial, norma dan sikap mempengaruhi perilaku petani dalam melaksanakan penanganan panen dan pasca panen gabah dan beras. Kemudian juga teknologi petani mempengaruhi perilaku petani dalam melaksanakan penanganan panen dan pasca panen gabah dan bears. Hal itu tercermin dari masih tingginya persentase susut hasil padi dan beras, meskipun inovasi dan teknologi dalam bentuk bimbingan teknis penanganan panen dan pasca panen gabah dan beras mulai panen, perontokan, pengeringan dan pengggilingan setiap tahun diadakan, begitu juga fasilitasi alsintan panen dan pasca panen padi dan beras yang terus dilaksanakan setiap tahun. Menurut Setyono (2008) titik kritis susut hasil padi dan terletak pada sistem pemanen dan perontokan.

Berdasarkan hal tersebut, perbaikan sistem penerapan panen dan pasca panen padi dan beras dalam upaya menekan susut hasil gabah dan beras harus mencakup seluruh sistem agribisnis dan aspek teknis, sosial, ekonomi, budaya dan kelembagaan petani / kelompok tani / Gapoktan setempat. Perbaikan tersebut harus menguntungkan semua pihak yang terlibat, baik petani pemilik, buruh panen, dan pengusaha jasa panen dan perontok. Dengan demikian, diperlukan pendekatan yang menyeluruh terhadap komponen-komponen sistem agar dapat menemukan sifat-sifat penting dalam sistem, sehingga diperoleh berbagai alternatif perbaikan keluaran yang dikehendaki. Karena itu, strategi untuk mengatasi susut hasil ini harus lebih dilihat dari bagaimana cara mengatasi faktor-faktor non teknis petani itu sendiri.

\section{METODE PENELITIAN}

Metode penelitian yang digunakan adalah two-phase mixed method (Creswell et. al., 2008). Fase pertama pada metode ini dimulai dengan pengumpulan literatur-literatur berupa dokumentasi berbagai instansi terkait seperti Dinas Pertanian, BPS dan instansi lainnya serta hasil-hasil penelitian dengan topik yang sama mengenai produktivitas dan susut hasil padi lalu dibandingkan dan dikaji secara mendalam untuk menggambarkan dinamika produktivitas dan variasi susut hasil padi di Jawa Barat.

Selanjutnya pada fase berikutnya digunakan data hasil survey pada daerah yang lebih spesifik untuk menghitung susut hasil dan menentukan faktor-faktor non teknis yang menentukan susut hasil padi. Data tersebut adalah data yang bersumber dari petani yang melakukan panen, perontokan, pengeringan dan penggilingan padi di kabupaten Indramayu pada musim tanam 2014/2015. Data mengenai susut hasil didapatkan dengan pengujian/pengukuran langsung di sawah milik petani yang bersangkutan, sedangkan data mengenai faktor-faktor non teknis didapatkan melalui wawancara. 
Penghitungan susut hasil mengikuti prosedur baku yang telah dikembangkan oleh BPS dan Deptan (2008). Rumus penghitungan susut hasil merupakan penjumlahan dari susut saat melakukan panen, susut saat melakukan perontokan, susut pengeringan dan susut penggilingan.

Metode analisis yang digunakan untuk menentukan faktor-faktor yang mempengaruhi susut hasil adalah analisis jalur (path analysis) dengan persamaan struktural yang berisi 15 buah variabel eksogen $X_{1}, X_{2}, \ldots, X_{15}$, dan sebuah variabel endogen yaitu persamaan struktural tersebut adalah:

$$
Y=\rho_{Y . x 1} X_{1}+\rho_{Y . x 2} X_{2}+\ldots+\rho_{Y . x 15} X_{15}+\varepsilon
$$

Keterangan:

$Y=$ Susut hasil gabah dan beras $(\mathrm{kg})$

$X_{1}=$ umur (tahun)

$X_{2}=$ Pendidikan

$X_{3}=$ Pengalaman usahatani (tahun)

$X_{4}=$ Tingkat pendapatan (Rp)

$X_{5}=$ Luas lahan (hektar)

$X_{6}=$ Pengawasan

$X_{7}=$ Perasaan

$X_{9}=$ Sanksi sosial

$X_{10}=$ Norma

$X_{11}=$ Sikap

$X_{13}=$ Perontokkan

$X_{14}=$ Pengeringan

$X_{15}=$ Penggilingan

$\rho_{Y . x i}=$ Koefisisen beta dari $X_{1}$ sampai $X_{15}$

$\varepsilon \quad=$ Kesalahan (disturbance term)

Selanjutnya, untuk menyusun strategi menanggulangi susut hasil gabah dan beras akibat dari faktor-faktor non teknis seperti perilaku sosial ekonomi, budaya dan teknologi petani pada setiap tahapanya, dilakukan analisis kualitatif dengan mengacu kepada identifikasi perilaku sosial ekonomi, budaya dan teknologi petani dalam melaksanakan panen dan pasca panen yang signifikan mempengaruhi susut hasil kemudian dilakukan kajian lebih mendalam dengan analisis kebijakan Timberben.

\section{HASIL DAN PEMBAHASAN}

Dinamika Produksi Padi Jawa Barat.

Jawa Barat merupakan salah satu sentra utama padi nasional, kontribusinya pada tahun 2014 sekitar $16 \%$. Rata-rata produksi padi Jawa Barat selama 1993-2014 tahun terakhir ini adalah sebesar 10.994.835 ton per tahun dengan rata-rata luas area panen seluas 1.927.089 hektar dan rata-rata produktivitas sebesar 5,70 ton/hektar.

Dalam hal produktivitas padi seperti tersaji pada Gambar 2, selama periode 19932014 rata-rata produktivitas padi Jawa Barat adalah 5,29 ton/hektar dengan standard deviation sebesar 0,43 ton/hektar. Jawa Tengah juga mempunyai rata-rata produktivitas padi yang hampir sama yaitu 5,285 ton/hektar namun mempunyai standard deviation yang lebih kecil yaitu 0,22 ton/hektar, ini menandakan variasi naik turunnya produktivitas padi Jawa Barat lebih berfluktuasi dari pada Jawa Tengah.

Selanjutnya Jawa Timur adalah provinsi dengan rata-rata produktivitas padi paling tinggi yaitu 5,44 ton/hektar dengan standard deviation sebesar 0,35 ton/hektar.

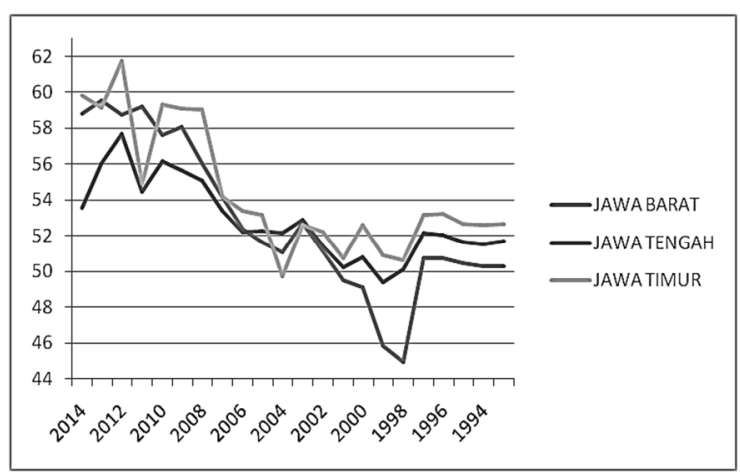

Gambar 2. Garafik Produktivitas Padi Jawa Barat, Jawa Tengah dan Jawa Timur periode 1993-2014 dalam kuintal per hektar Sumber: Data BPS, diolah 2015

Dengan rata-rata produktivitas yang lebih kecil dan standard deviation yang lebih besar dari Jawa Timur mengindikasian bahwa terdapat penurunan produktivitas padi yang sangat tajam atau laju pertumbuhan produktivitas yang lebih lambat di Jawa Barat. Seperti pada tahun 1998 di mana hampir semua daerah mengalami penurunan produktivitas namun Jawa Barat mengalami penurunan produktivitas yang sangat tajam hingga hanya mencapai 4,5 ton/hektar.

Jawa Barat sebenarnya awalnya pada tahun 1993 merupakan yang paling rendah produktivitasnya diantara Jawa Tengah dan Jawa Timur. Namun walaupun saat ini produktivitas Jawa Barat masih lebih rendah dibandingkan Jawa Timur namun saat ini sudah lebih tinggi dari Jawa Tengah. 
Dinamika Variasi Susut Hasil Padi. Persentase susut hasil padi di Jawa Barat ditunjukkan pada Tabel 2 berikut.

Tabel 2. Persentase Susut Hasil Padi di Jawa Barat Tahun 2009, 2010, dan 2011

\begin{tabular}{lccc}
\hline \multirow{2}{*}{ Tahapan } & \multicolumn{3}{c}{ Persentase Susut Hasil (\%) } \\
\cline { 2 - 4 } & Tahun & Tahun & Tahun \\
& 2009 & 2010 & 2011 \\
\hline Panen & 3.48 & 2.29 & 3.07 \\
Perontokan & 3.82 & 3.06 & 3.2 \\
Pengeringan & 2.35 & 3.31 & 3.06 \\
Penggilingan & 1.69 & 2.39 & 2.13 \\
Jumlah & 11.34 & 11.05 & 11.46 \\
\hline
\end{tabular}

Sumber: Diperta Provinsi Jawa Barat, (2012)

Dengan tingkat susut hasil sebesar $11,46 \%$, gabah yang tercecer sebesar $1.447 .138,4$ ton berasal pada saat panen $387.671,44$ ton GKP, perontokan 404.087,51 ton GKP, pengeringan $386.408,68$ ton GKP dan penggilingan 268.970,75 ton GKG. Susut hasil ini, jika dikonversikan ke dalam luas areal sawah dengan rata-rata produksi Gabah Kering Panen (GKP) di Jawa Barat yang sebesar 5,6 ton per hektar sama dengan $258.417,5$ ha sawah tidak dipanen. Kemudian jika dikonversikan ke dalam Harga Pembelian Petani (HPP) GKP Rp.3,300,- ditingkat petani dan GKG Rp.4,200,- per kg di Perum BULOG (Inpres No.3. Tahun 2012) dari panen, perontokan dan pengeringan, Gabah Kering Panen (GKP) yang tercecer setara dengan Rp.3,887,953,179,000,-, sedangkan untuk penggilingan Gabah Kering Giling yang tercecer $(\mathrm{GKG})$ setara dengan Rp.1,129,677,150,000,-.

Berdasarkan Tabel 2, dinamika variasi susut hasil cenderung relative tetap pada level $11-12 \%$ dengan standard deviation sebesar $0,21 \%$. Angka ini jelas masih terlalu tinggi dan belum terlihat kecenderungan untuk menurun. Maka dari itu, angka susut hasil ini harus segera diturunkan agar program peningkatan produksi padi di Jawa Barat dapat berjalan lebih efisien dan efektif. Selain itu, jika permasalahan susut hasil padi di Jawa Barat yang angkanya cukup tinggi ini dapat diatasi dengan baik maka produktivitas padi Jawa Barat dapat lebih baik lagi dan berpeluang untuk mengungguli Jawa Timur.

Dinamika Produktivitas dan Susut Hasil di Indramayu. Kabupaten Indramayu merupakan kabupaten penghasil padi terbesar di Jawa Barat. Selama periode 2009-2013, rata-rata produksi padi Indramayu adalah 1.311.664 ton, disusul oleh kabupaten Karawang dan Subang dengan 1.098.891 ton dan 1.013.195 ton (Disperta Jabar, 2014).

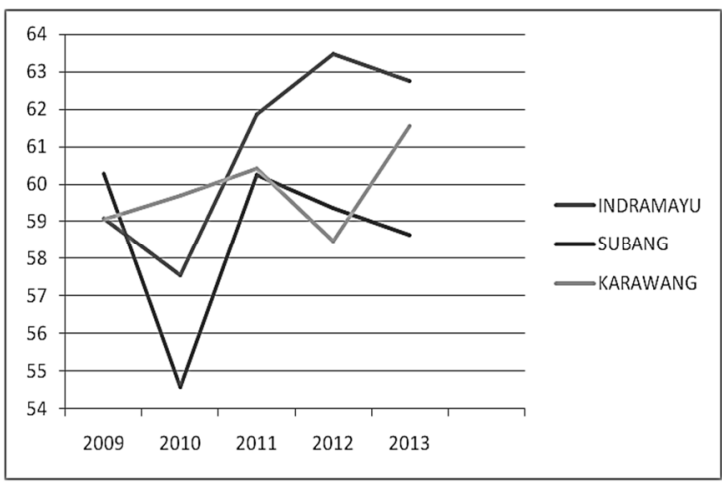

Gambar 2. Grafik Produktivitas Padi Kabupaten Indramayu, Subang dan Karawang periode 2009-2013 dalam kuintal per hektar

Sumber: Disperta Provinsi Jawa Barat, diolah 2015

Gambar 2 menunjukkan bahwa dalam hal produktivitas padi, Kabupaten Indramayu memiliki rata-rata produktivitas tertinggi. Selama periode 2009-2013 angkanya mencapai 6,09 ton/hektar di atas Karawang dan Subang yang masing-masing sebesar 5,98 ton/hektar dan 5,86 ton/hektar. Namun demikian, jika dilihat dari nilai standard deviation produktivitasnya dalam periode yang sama, Indramayu memiliki nilai standard deviation yang lebih besar dari pada Karawang dan Subang. Nilai standard deviation produktivitas padi Indramayu adalah 0,25 ton/hektar, Subang sebesar 0,23 ton/hektar dan Karawang sebesar 0,12. Dalam hal ini Kabupaten Indramayu adalah yang paling tinggi fluktuasi naik turunnya. Kejadian susut hasil tidak bisa dikecualikan sebagai salah satu penyebabnya. Untuk itu, hasil survey mengenai susut hasil di Indramayu akan dipaparkan dan dianalisis lebih jauh. Hasil penghitungan susut hasil di Kabupaten Indramayu disajikan pada Tabel 3 berikut.

Tabel 3. Hasil Penghitungan Susut Hasil di Kabupaten Indramayu

\begin{tabular}{lllll}
\hline \multirow{2}{*}{ Statistik } & \multicolumn{4}{l}{ Susut Hasil $(\mathrm{kg})$} \\
\cline { 2 - 5 } & Panen & $\begin{array}{l}\text { Peron- } \\
\text { tokan }\end{array}$ & $\begin{array}{l}\text { Penge- } \\
\text { ringan }\end{array}$ & $\begin{array}{l}\text { Penggi- } \\
\text { lingan }\end{array}$ \\
\hline Rata-rata & 2.68 & 13.43 & 0.47 & 0.034 \\
Simpangan baku & 1.92 & 4.27 & 1.99 & 0.045
\end{tabular}

Sumber: Data Primer diolah, (2015) 
Faktor utama dari masih tinginya susut hasil gabah pada saat panen disebabkan petani masih mengunakan sistem keroyokan. Dalam sistem keroyokan berkisar antara 20 - 30 orang pemanen yang seringkali dilakukan malam hari pemanen dengan menggunakan sabit biasa berebut memotong padi, akibatnya banyak rumpun padi yang terinjak dan patah. Pengunaan sabit biasa menyebabkan tekanan terhadap rumpun padi sangat besar ketika batang padi dipotong sehingga banyak butir gabah yang jatuh. Berbeda halnya jika menggunakan sabit bergerigi, karena tekanan terhadap rumpun padi ketika batang padi dipotong lebih rendah daripada sabit biasa. Menurut Damarjati et al, (1990) sabit bergerigi bisa menekan kehilangan hasil pada saat pemotongan padi sebesar 3\%. Selain itu, padi yang telah dipanen dikumpulkan ditengah sawah dengan alas terpal plastik untuk dirontokan di pagi hari, penundaan perontokan ini akan mempengaruhi kualitas gabah dan peningkatkan risiko kehilangan hasil.

Berdasarkan Tabel 3, rata-rata susut hasil pada saat perontokan adalah yang paling tinggi dibandingkan tahapan lainnya. Hal ini terjadi karena di lokasi penelitian atau umumnya di Indramayu padi dirontokan dengan alat banting bertirai tanpa penghalang, jumlah batang padi seringkali lebih besar dari genggaman tangan sehingga tidak terbanting dengan baik, jumlah bantingan antara 2-4 kali sehingga masih terdapat butir padi yang menempel di malainya dan batang padi yang berjatuhan. Selain itu, ketika panen berakhir diikuti oleh pengeprek (padi diorek-orek) atau remi (ngorek-nogrek jerami) yang di drop per mobil antara 10-15 orang yang berasal dari Desa sekitarnya. Berdasarkan hasil wawancara dengan Momo 34 tahun (2013) salah satu pengeprek hasilnya dapat mencapai 30-60 kg per bau gabah bernas per orangnya. Hasil ngeprek dijual kepada bandar pemilik mobil dengan harga Rp.3000,- Rp.3500,- per kg. Ngeprek sudah menjadi kebiasaan di Indramayu dan jika pemilik sawah melarang maka seringkali padi yang siap panen diganggu.

Kemudian pada proses pengeringan, padi dikeringkan ditengah sawah atau atau dihalaman rumah, sambil dijemur biasa dibersihkan. Petani menggunakan karung plastik atau terpal plastik sebagai alasnya. Disamping terjadi susut hasil karena tercecer juga seringkali adanya gangguan dari burung dan ayam yang biasa berkeliaran disekitar rumah. Namun demikian dari Tabel 2 didapatkan nilai simpangan baku susut hasil pengeringan sebesar 1,99 yang jauh lebih tinggi dari pada rata-ratanya, hal ini menunjukkan sangat bervariasinya tingkat susut hasil petani pada saat melakukan pengeringan hasil panen.

Kemudian yang terakhir pada proses penggilingan nilai susut hasilnya adalah yang paling kecil. Pada tahapan ini, susut hasilnya berupa gabah yang tercecer disekitar mesin penggiling, dan menir (beras patah) banyaknya beras patah ini disebabkan oleh kadar air yang kurang dari $14 \%$ atau lebih dari $14 \%$. Biasa petani dalam mengeringkan gabah antara $12-$ $15 \%$ akibatnya banyak terjadi butir hijau, butir mengapur (chalky), dan menir (beras patah).

Namun demikian, susut hasil penggilingan ini merupakan keuntungan bagi pemilik penggilingan. Berdasarkan hasil wawancara dengan Wagiono (2013) salah satu pemilik penggilingan padi menir dan dedak merupakan keuntungan pemilik penggilingan padi disamping biaya penggilingan. Menir diayak dengan ayakan halus menjadi tiga bagian yaitu menir patah dua dijual Rp.600,- per kg, menir patah tiga Rp.4,500,- per kg dan menir bebek (> patah 3) dijual Rp.4,000,- per kg sementara dedak dijual Rp.2,500,- per kg.

\section{Faktor-Faktor Non Teknis yang} Mempengaruhi Susut Hasil Padi. Berikut adalah hasil estimasi faktor-faktor non tenis yang menjadi determinan terhadap pendapatan petani mangga setelah memenuhi asumsiasumsi klasik dan goodness of fit. Dari hasil analisis akhir didapatkan 5 faktor yang mempengaruhi susut hasil $(Y)$ secara nyata yaitu tingkat pendapatan usahatani $\left(X_{4}\right)$, luas lahan $\left(X_{5}\right)$, perasaan $\left(X_{7}\right)$, norma $\left(X_{10}\right)$ dan penggilingan $\left(X_{15}\right)$.

Tabel 4. Faktor-faktor Non Teknis yang Menjadi Determinan terhadap Susut Hasil

\begin{tabular}{|c|c|c|c|}
\hline Variabel & $\begin{array}{l}\text { Koefisien } \\
\operatorname{Jalur}\left(\rho_{Y . x i}\right)\end{array}$ & $\begin{array}{l}\text { Tingkat } \\
\text { Signifikansi }\end{array}$ & Status \\
\hline$X_{4}$ & 0,877 & $0,000 * * *$ & Signifikan \\
\hline$X_{5}$ & $-0,468$ & $0,020 * *$ & Signifikan \\
\hline$X_{7}$ & 0,357 & $0,010 * * *$ & Signifikan \\
\hline$X_{10}$ & $-0,368$ & $0,005 * * *$ & Signifikan \\
\hline$X_{15}$ & 0,357 & $0,007 * * *$ & Signifikan \\
\hline Uji-F & & $0,000^{* *}$ & Signifikan \\
\hline \multicolumn{4}{|c|}{$R^{2}=0,383$} \\
\hline
\end{tabular}

Ket: $(*)$ Signifikan dengan tingkat kepercayaan 90\% (**) Signifikan dengan tingkat kepercayaan 95\% (***) Signifikan dengan tingkat kepercayaan 99\% Sumber: Data Primer diolah, (2015) 
Tabel 5. Matriks Korelasi Antar Variabel

\begin{tabular}{lllllll}
\hline$r_{x i x j}$ & $\mathrm{Y}$ & $\mathrm{X}_{4}$ & $\mathrm{X}_{5}$ & $\mathrm{X}_{7}$ & $\mathrm{X}_{10}$ & $\mathrm{X}_{15}$ \\
\hline $\mathrm{Y}$ & 1,000 & 0,361 & 0,169 & 0,071 &, 172 & 0,161 \\
$\mathrm{X}_{4}$ & 0,361 & 1,000 & 0,761 & 0,203 & 0,128 & $-0,113$ \\
$\mathrm{X}_{5}$ & 0,169 & 0,761 & 1,000 & 0,066 & 0,014 & $-0,136$ \\
$\mathrm{X}_{7}$ & 0,071 & ), 203 & 0,066 & 1,000 & 0,010 & $-0,205$ \\
$\mathrm{X}_{10}$ & 0,172 & 0,128 & 0,014 & 0,010 & 1,000 & 0,239 \\
$\mathrm{X}_{15}$ & 0,161 & ), 113 & 0,136 & J,205 & 0,239 & 1,000 \\
\hline
\end{tabular}

Sumber: Data Primer diolah, (2015)

Dari Tabel 4 dan Tabel 5 didapatkan nilai pengaruh langsung dan tidak langsung dari ke-5 faktor tersebut.

Tabel 6. Pengaruh Langsung, Pengaruh Tidak Langsung, dan Pengaruh Total Faktor Pendapatan $\left(X_{4}\right)$ terhadap Tingkat Susut Hasil Gabah dan Beras

\begin{tabular}{lll}
\hline Pengaruh langsung & & 0,7688 \\
Pengaruh tidak langsung : & Melalui $X_{5}$ & $-0,3124$ \\
& Melalui $X_{7}$ & $-0,0634$ \\
& Melalui $X_{10}$ & $-0,0413$ \\
& Melalui $X_{15}$ & $-0,0353$ \\
Pengaruh total $X_{4}$ ke $Y$ & & 0,3162 \\
\hline
\end{tabular}

Berdasarkan Tabel 6, secara langsung peningkatan tingkat susut hasil gabah dan beras sebesar 76,88\% ditentukan oleh faktor tingkat pendapatan. Namun jika dilihat dari pengaruh total tidak langsung faktor tingkat pendapatan melalui luas lahan, perasaan, norma dan penggilingan berubah menjadi $45,25 \%$ yang berarti menurunnya tingkat susut hasil gabah dan beras sebesar $45,25 \%$ ditentukan oleh perbaikan dan peningkatan berbagai aspek dari faktor luas lahan, perasaan, norma dan penggilingan. Pengaruh total tidak langsung ini mengurangi total pengaruh pendapatan terhadap tingkat susut hasil gabah dan beras menjadi $31,62 \%$, jadi meningkatnya tingkat susut hasil gabah dan beras sebesar $31,62 \%$ secara total ditentukan oleh faktor tingkat pendapatan.

Hasil analisis mengungkapkan bahwa peningkatan pendapatan berkontribusi pada meningkatnya susut hasil. Dalam hal ini tinggnya pendapatan ini disebabkan karena petani kurang menganggarkan biaya untuk sistem budidaya yang lebih baik dan perlakuan panen dan pasca panen yang baik. Untuk itu, petani harus didorong untuk lebih memperhatikan pembiayaan pada sistem budidaya/produksi untuk meningkatkan produktivitas dan perlakuan panen dan pasca panen untuk menurunkan susut hasil. Sehingga walaupun hal ini akan meningkatkan biaya produksi namun akan tertutup oleh meningkatkan hasil dan sedikitnya susut hasil padi.

Tabel 7. Pengaruh Langsung, Pengaruh Tidak Langsung, dan Pengaruh Total Faktor Luas Lahan $\left(X_{5}\right)$ terhadap Tingkat Susut Hasil Gabah dan Beras

\begin{tabular}{lll}
\hline Pengaruh langsung & & 0,2194 \\
Pengaruh tidak langsung & Melalui $X_{4}$ & $-0,3124$ \\
& Melalui $X_{7}$ & $-0,0111$ \\
& Melalui $X_{10}$ & 0,0023 \\
& Melalui $X_{15}$ & 0,0228 \\
Pengaruh total $X_{5}$ ke $Y$ & & $-0,0790$ \\
\hline
\end{tabular}

Berdasarkan Tabel 7, secara langsung peningkatan tingkat susut hasil gabah dan beras sebesar $21,94 \%$ ditentukan oleh faktor luas lahan. Namun jika melihat pengaruh total tidak langsung faktor luas lahan melalui tingkat pendapatan, perasaan, norma dan penggilingan bernilai negatif $-29,84 \%$ yang berarti penurunan tingkat susut hasil gabah dan beras sebesar 29,84\% secara tidak langsung ditentukan oleh perbaikan dan peningkatan faktor-faktor pendapatan, perasaan, norma dan penggilingan. Pengaruh total tidak langsung ini mengurangi total pengaruh luas lahan terhadap tingkat susut hasil gabah dan beras menjadi $-7,90 \%$, jadi menurunnya tingkat susut hasil gabah dan beras sebesar 7,90\% secara total ditentukan oleh faktor luas lahan.

Tabel 8. Pengaruh Langsung, Pengaruh Tidak Langsung, dan Pengaruh Total Faktor Perasaan $\left(X_{7}\right)$ terhadap Tingkat Susut Hasil Gabah dan Beras

\begin{tabular}{lll}
\hline Pengaruh langsung & & 0,1275 \\
Pengaruh tidak langsung & Melalui $X_{4}$ & $-0,0634$ \\
& Melalui $X_{5}$ & $-0,0111$ \\
& Melalui $X_{10}$ & $-0,0014$ \\
& Melalui $X_{15}$ & $-0,0262$ \\
Pengaruh total $X_{7}$ ke $Y$ & & 0,0254 \\
\hline
\end{tabular}

Berdasarkan hasil analisis, menurunkan susut hasil disebabkan karena semain luasnya lahan petani. Dalam hal ini terdapat kecenderungan bahwa petani dengan luas lahan $\geq 0,7$ hektar cenderung berupaya untuk memaksimalkan biaya produksi dan menggunakan teknologi baik untuk produksi, panen dan pasca panen untuk mendapatkan hasil panen yang maksimal. Untuk itu, petani dengan luas lahan kurang dari 0,7 hektar yang kebanyakan 
bermodal seadanya perlu mendapatkan perhatian dengan adanya bantuan permodalan agar dapat melakukan hal dilakukan petani yang luas lahannya lebih dari 0,7 hektar.

Tabel 8 menunjukan bahwa secara langsung peningkatan tingkat susut gabah dan beras sebesar $12,75 \%$ ditentukan oleh faktor perasaan. Namun jika dilihat dari pengaruh total tidak langsung perasaan melalui faktor pendapatan, luas lahan, norma dan penggilingan berpengaruh negatif sebesar $10,21 \%$ yang berarti secara tidak langsung penurunan tingkat susut hasil gabah dan beras sebesar $10,21 \%$ ditentukan oleh perbaikan dan peningkatan dari faktor faktor tingkat pendapatan, luas lahan, norma dan penggilingan. Pengaruh total tidak langsung ini mengurangi total pengaruh perasaan terhadap tingkat susut hasil gabah dan beras menjadi $2,54 \%$, jadi meningkatnya tingkat susut hasil gabah dan beras sebesar 2,54\% secara total ditentukan oleh faktor perasaan.

Tabel 9. Pengaruh Langsung, Pengaruh Tidak Langsung, dan Pengaruh Total Faktor Norma $\left(X_{10}\right)$ terhadap Tingkat Susut Hasil Gabah dan Beras

\begin{tabular}{lll}
\hline Pengaruh langsung & & 0,1351 \\
Pengaruh tidak langsung & Melalui $X_{4}$ & $-0,0413$ \\
& Melalui $X_{5}$ & 0,0023 \\
& Melalui $X_{7}$ & $-0,0014$ \\
& Melalui $X_{15}$ & $-0,0314$ \\
Pengaruh total $X_{10}$ ke $Y$ & & 0,0634 \\
\hline
\end{tabular}

Tabel 9 menunjukan bahwa secara langsung peningkatan tingkat susut gabah dan beras sebesar $13,51 \%$ ditentukan oleh faktor norma. Namun jika dilihat dari pengaruh tidak langsung faktor norma melalui pendapatan, luas lahan, perasaan, dan penggilingan berpengaruh negatif sebesar $-7,18 \%$ yang berarti penurunan tingkat susut hasil gabah dan beras sebesar 7,18\% secara tidak langsung ditentukan oleh perbaikan dan peningkatan dari faktor pendapatan, luas lahan, perasaan, dan penggilingan. Pengaruh total tidak langsung ini mengurangi total pengaruh norma terhadap tingkat susut hasil gabah dan beras menjadi 6,34\%. Jadi meningkatnya tingkat susut hasil gabah dan beras sebesar 6,34\% secara total ditentukan oleh faktor norma. Jika dibandingkan antara pengaruh tidak langsung perasaan $-10,21 \%$ dengan total pengaruh perasaan $2,54 \%$ jauh lebih besar pengaruh total tidak langsung, artinya sebenarnya dengan meningkatkan rasionalitasnya dan mengurangi unsur menjaga perasaan petani seperti membatasai jumlah pemanen, menggunakan perontok mesin, mengeringkan dalam lamporan, dan menggiling di penggilingan besar mereka dapat menurunkan susut hasilnya. Namun hal ini tidak dilakukan. Di lokasi penelitian sudah biasa siapa saja bisa ikut panen meskipun pemilik sawah tidak menyuruhnya, bahkan ketika panen sedang berlangsung orang bisa langsung ikut panen. Pemilik sawah menyadari hal itu merugikan karena semakin banyak jumlah pemanen maka kerusakan padi akibat terinjak karena berebut akan semakin banyak, namun tidak bisa melarangnya karena karena empati terhadap orang lain dan takut orang tersebut akan tersinggung dan marah.

Artinya kesadaran akan kerugian dengan mempertahankan norma-norma yang berlaku ketika melaksanakan sistem panen, perontokan pengeringan dan penggilingan ada. Namun kesadaran ini tidak dinyatakan dalam tindakan karena norma-norma itu sudah menjadi kebiasaan. Sangat sulit untuk merubah kebiasaan-kebiasaan yang ada dalam masyarakat pedesaan, karena itu sudah lama terjadi dan sudah menjadi patokan dalam perilaku sehari-hari seseorang yang melanggar norma akan dikenai sangsi sosial dari masyarakat disekitarnya.

Tabel 10. Pengaruh Langsung, Pengaruh Tidak Langsung, dan Pengaruh Total Faktor Penggilingan $\left(X_{15}\right)$ terhadap Tingkat Susut Hasil Gabah dan Beras

\begin{tabular}{lll}
\hline Pengaruh langsung & & 0,1276 \\
Pengaruh tidak langsung & Melalui $X_{4}$ & $-0,0353$ \\
& Melalui $X_{5}$ & 0,0228 \\
& Melalui $X_{7}$ & $-0,0262$ \\
& Melalui $X_{10}$ & $-0,0314$ \\
Pengaruh total $X_{15}$ ke $Y$ & & 0,0575 \\
\hline
\end{tabular}

Tabel 10 menunjukan secara langsung peningkatan tingkat susut hasil gabah dan beras ditentukan oleh faktor penggilingan sebesar $12,76 \%$. Namun jika dilihat dari pengaruh total tidak langsung penggilingan melalui faktor pendapatan, luas lahan, perasaan, dan norma sebesar $-7,01 \%$. Jadi pengaruh langsung penggilingan terhadap tingkat susust hasil gabah dan beras yang tadinya positif setelah melalui faktor pendapatan, perasaan, dan norma berubah menjadi negatif, namun tetap positif ketika 
melalui faktor luas lahan meskipun sangat kecil. Ini berarti bahwa secara tidak langsung tingkat susut hasil gabah dan beras sebesar 7,01\% dapat diturunkan melalui perbaikan dan peningkatan dari faktor faktor pendapatan, perasaan, dan norma. Pengaruh total tidak langsung ini mengurangi total pengaruh langsung penggilingan terhadap tingkat susut hasil gabah dan beras menjadi 5,75\%. Jadi secara total faktor penggilingan dapat meningkatkan tingkat susut gabah dan beras sebesar $5,75 \%$.

Hal itu terjadi karena sebagian besar petani dilokasi penelitian menggiling padinya ke Penggilingan Padi Kecil (PPK) dengan kategori I Phase milik petani lainnya atau milik kelompok taninya yang sudah berumur tua dan proses penyosohannya secara abrasif. Menurut Nugraha dan Tim, (2008) mesin penggilingan I Phase adalah pengilingan padi dimana mesin pemecah kulit (husker) menyatu dengan mesin penyosoh (polisher). Gabah dimasukan ke dalam hooper hasilnya beras pecah kulit, kemudian dimasukan lagi hasilnya menjadi beras. Implikasi kebijakan dapat difokuskan pada modernisasi di bidang pertanian melalui bimbingan teknis penanganan panen dan pasca panen gabah dan beras dan fasilitasi alsintan terutama revitalisasi pengilingan padi dari I Phase menjadi II Phase.

\section{KESIMPULAN}

Dinamika produktivitas padi di Jawa Barat cenderung memiliki fluktuasi yang lebih tajam dan laju pertumbuhan yang lebih lambat pada produtivitas padi Jawa Barat dibandingkan Jawa Tengah dan Jawa Timur. Tinjauan dari segi variasi susut hasil pun cenderung relative masih terlalu tinggi dan belum ada kecenderungan untuk menurun. Susut hasil ini harus segera diatasi agar program peningkatan produksi padi dapat berjalan lebih efisien dan efektif.

Berdasarkan analisis simultan faktor pendapatan, luas lahan, perasaan, norma dan penggilingan mempengaruhi tingkat susut hasil gabah dan beras sebesar 38,34\%, dan $61,66 \%$ dipengaruhi oleh faktor-faktor lain diluar penelitian ini. Dari variabel ekonomi diwakili oleh faktor pendapatan dan luas lahan. Peningkatan tingkat susut hasil gabah dan beras sebesar 31,62\% secara total dipengaruhi oleh tingkat pendapatan, namun menurunnya tingkat susut hasil gabah dan beras sebesar
$7,90 \%$ secara total dipengaruhi oleh faktor luas lahan. Dari variabel teknologi petani diketahui bahwa naiknya tingkat susut hasil gabah dan beras sebesar $5,75 \%$ secara total dipengaruhi oleh faktor penggilingan. Sedangkan dari variabel budaya naiknya tingkat susut hasil gabah dan beras sebesar 2,54\% secara total dipengaruhi oleh faktor perasaan, dan sebesar $6,34 \%$ secara total dipengaruhi oleh faktor norma.

Berdasarkan uraian di atas, untuk mengatasi penurunan produktivitas karena tingginya tingkat susut hasil dapat dibuat implikasi kebijakan diantaranya:

1) Petani harus didorong untuk lebih memperhatian pembiayaan untuk perlakuan panen dan pasca panen padi untuk menurunkan susut hasil.

2) Memberikan bantuan modal untuk petani yang luas lahannya kurang dari 0,7 hektar.

3) Melakukan pendekatan budaya yang dapat merubah penanganan panen dan pasca panen menjadi lebih baik dan tidak mengakibatkan disharmoni diantara petani dan buruh tani (buruh panen) dan saling menguntungkan kedua belah pihak.

4) Modernisasi penanganan panen dan pasca panen melalui pemberian bantuan fasilitas alsintan terutama revitalisasi pengilingan padi dari I Phase menjadi II Phase dan bimbingan teknis untuk meningkatkan kualitas SDM-nya.

\section{DAFTAR PUSTAKA}

BPS dan Departemen Pertanian. (2008). Laporan Hasil Survei Susut Panen Dan Pasca Panen Gabah/Beras. Kerjasama Badan Pusat Statistik Dan Departemen Pertanian. Jakarta.

BPS. (2015). Luas Lahan, Produktivitas, dan Produksi Padi Jawa Barat, Jawa Tengah dan Jawa Timur. Melalui situs www.bps.go.id.

Creswell, J.W. and V.L.P. Clark. (2008). Designing and Conducting Mixed Methods Research. Sage Publications. London.

Damardjati, Djoko Said. (2010). Kebijakan Pemerintah Dalam Peningkatan Mutu dan Nilai Tambah Pengolahan Gabah/Beras. Direktur Jenderal Pengolahan dan Pemasaran Hasil Pertanian. Prosiding Lokakarya Nasional.

Diperta Provinsi Jawa Barat. (2014). Luas Tanam, Luas Panen, Produksi dan 
Produktivitas Padi Sawah Menurut Kabupaten Dan Kota Tahun 2009 2013 di Jawa Barat. Melalui situs http://diperta.jabarprov.go.id/index.php/ subMenu/1780.

Enrico. (2012). Teknologi Penanganan Panen Dan Pasca Panen Padi Dalam Menekan Susut Hasil. Makalah. (BPPP) Balai Besar Penelitian Pasca Panen, Bogor. Iswari, K. (2012). Kesiapan Teknologi Panen dan Pascapanen Padi dalam Menekan Kehilangan Hasil dan Meningkatkan Mutu Beras. Jurnal Litbang Pertanian.

Nhamo, N., J. Rodenburg, N. Zenna, G. Makombe and A.L. Kihupi. (2014). Narrowing the rice yield gap in East and Southern Africa: Using and Adapting Existing Technologies. Elsevier. Nugraha, Sigit dan Tim. (2008). Metode Menekan Kehilangan Hasil Padi. Balai Besar Litbang Pascapanen Pertanian. Bogor.
Oerke, E.C., H.W. Dehne, E. Schonbeck, and A. Weber. (1999). Crop Producing and Crop Protection: Estimated Lossing in Major Food and Cash Crop. Elsevier. Netherland.

Raharjo, B., D. Hadiyanti, dan K. A. Kodir. (2012). KajianKehilangan Hasil Pada Pengeringan dan Penggilingan Padi di Lahan Pasang Surut Sumatera Selatan. Jurnal Lahan Suboptimal. Vol. 1, No.1: 72-82.

Rasmikayati, E. (2014). Perubahan Iklim: Dampaknya Terhadap Perilaku Serta Pendapatan Petani. Bandung.

Setyono, Agus. (2008). Teknologi Penanganan Pasca Panen Padi. Makalah. Disampaikan Pada Lokakarya Kegiatan Pengkajian Pemanfaatan Alat Dan Mesin Pertanian (Alsintan Pasca Panen Padi Sawah. Badan Penelitian Dan Pengembangan Daerah Provinsi Jawa Barat, Bandung Desember 2008. 